\title{
Subalpine vegetation in Giresun Mountains (Turkey)
}

\author{
Rena Hüseyinova ${ }^{1}$, Erkan Yalçin ${ }^{2 *}$ \\ ${ }^{1}$ Şebinkarahisar School of Applied Sciences, Giresun University, Giresun, Turkey \\ ${ }^{2}$ Department of Biology, Faculty of Arts and Science, Ondokuz Mayıs University, Samsun, Turkey
}

\begin{abstract}
In this study, the subalpine vegetation in the Giresun Mountains of northern Turkey was investigated. The study area included north- and south-facing slopes at altitudes ranging between c. 2000 and 2500 meters. For vegetation classification and for describing the relationships between vegetation and environment, traditional Braun-Blanquet methods and multivariate analysis techniques were used. The vegetation mainly consisted of subalpine grasslands and coniferous cushion scrubs. Caricetea curvulae and Astragalo microcephali-Brometea tomentelli were found to be dominant syntaxa in the vegetation of the study area. Land topography, soil physical and chemical factors and species richness have important impacts on the development of subalpine vegetation according to the results of multivariate analysis. Three associations and two subassociations were newly determined and classified. Hemicryptophytes, chamaephytes and geophytes participated in the floristic composition of these syntaxa. EUNIS habitat code and names for described syntaxa were also proposed.
\end{abstract}

Keywords: environment, grasslands, life form, phytosociology, species richness, syntaxonomy

\section{Introduction}

Mountainous areas are mainly located in the northern hemisphere (Vogiatzakis 2012) and orographic, edaphic and climatic factors have drawn an alpine borderline in these mountainous areas (Holtmeier and Broll 2005). Alpine and subalpine belts of mountains form specific ecological conditions for vascular flora and vegetation due to geographical isolation, glaciation, the existence of microhabitats, climatic and historical changes (Uysal et al. 2011). Subalpine vegetation is greatly influenced by different types of natural and anthropogenic disturbance (Tappeiner et al. 1998) and is rather sensitive to global climate change (Cannone et al. 2007). It is expected that the subalpine plant composition will be changed by upward species migration due to ongoing global climate changes. These changes have been observed by the GLORIA monitoring network (GLORIA-Europe = Global Observation Research Initiative in Alpine Environments and GLORIA-worldwide) in high mountain regions. Subalpine and alpine grasslands are considered biodiversity hotspots and included in the NATURA 2000 network as an EU priority habitat type (Pfeiffer et al. 2016).

Syntaxonomic and ecological investigations on alpine and subalpine belts have been carried out by many researchers in Europe and Asia. The first vegetation investigation on alpine vegetation in western and southern Anatolia was done by Quézel and Pamukçuoğlu (1970) and Quézel (1973). Rehder et al. (1994) and Hein et al. (1998) researched new alpine plant syntaxa in Uludag-Bursa province from Turkey. In these studies, the alpine vegetation was mostly included in the class Astragalo microcephali-Brometea tomentelli Quézel $1973 \mathrm{em}$. Parolly and its five orders. These orders include following vegetation types; 1 - Astragalo microcephali-Brometalia tomentelli Quézel 1973: Oreal to subalpine xerophytic grasslands, dwarf-shrub and the thorny-cushion communities of Anatolia, 2- Drabo-Androsacetalia Quézel 1979: Alpine to subnival mat-forming communities, 3- Hyperico linarioidisThymetalia skorpilii Akman, Quézel, Yurdakulol, Ketenoğlu, Demirörs 1987: Xerophytic grasslands, dwarf-shrub and thorny-cushion communities of the West and Middle Black Sea Mountains, 4- Onobrychido armenae-Thymetalia leucostomi Akman, Ketenoğlu, Quézel \& Demirörs 1984: Xerophytic grasslands, dwarf-shrub and the thorny-cushion communities of Central Anatolia, 5- Trifolio anatolici-Polygonetalia arenastri Quézel 1973: Hygrophytic to mesophytic vegetation of dolines, snow-patch and the melt water communities of the Taurus range (Hamzaoğlu 2006).

* Corresponding author, e-mail: eryalcin@omu.edu.tr 
Turkish phytosociologists and ecologists have mostly concentrated on the forest and steppe vegetation in mountainous areas in Turkey (Parolly 2004). Alpine and subalpine vegetation studies were mostly carried out under the leadership of foreign researchers in Turkey. However, some of the Turkish botanists such as Akman et al. (1987), Tatl (1987), Düzenli (1988), Kılınç and Karakaya (1992), Vural (1996), Uysal et al. (2011) partly focused on alpine and subalpine vegetation. Vural (1996) published a comprehensive syntaxonomic scheme about the alpine belts of mountains of the Eastern Black Sea, while Hein (1998) and Parolly (1998, 2004) did important revision for some of the syntaxa in the alpine vegetation of the West and Eastern Taurus Mountains. Although the syntaxonomic classification of vegetation is very important, the relationships between vegetation and environment have not been sufficiently investigated for alpine and subalpine vegetation in Turkey. The phytosociological approach of vegetation classification considered that each community is evolved by a site-specific range of environmental factors leading to differences in species composition (Vonlanthen et al. 2006).

The aim of this study was to describe syntaxa and the relationships between vegetation and environmental properties of the subalpine communities in Giresun Mountains from northern Turkey.

\section{Materials and methods}

\section{Study area}

The study area is situated at A7 according to the grid system of Davis $(1965,1985)$, and is approximately located

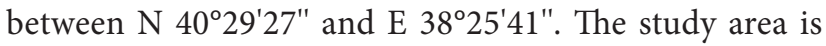
surrounded by high mountains. In the study area, the subalpine belt extends from c. 2000 to 2500 m upwards on south and north-facing slopes. Giresun Mountains are a system of mountains that extend up to the peaks on $\mathrm{Mt}$ Karadağ, $3391 \mathrm{~m}$, in the east and on the Karagöl plateau with $3095 \mathrm{~m}$ in the west. The study area is located in the north of Şebinkarahisar, between the Eastern Pontide Metallogenic Belt and the North Anatolian Fault system (Yavuz et al. 2008). The Turkish Pontides comprise the Cretaceous to Eocene igneous record of the convergence between Eurasia and Gondwana (Boztuğ et al. 2004)

The nearest district to the study area (Şebinkarahisar) has a Mediterranean type of climate with $525 \mathrm{~mm}$ mean annual precipitation (P), and a drought period is observed in July with $0.5 \mathrm{~mm}$ precipitation according to the Şebinkarahisar State Meteorological Station. The mean annual temperature is $11.3{ }^{\circ} \mathrm{C}$. Summer rainfall (PE) is $37 \mathrm{~mm}$. The mean maximum for the hottest month $(\mathrm{M})$ and mean minimum for the coldest month $(\mathrm{m})$ are 30.3 and $-16.1^{\circ} \mathrm{C}$, respectively. Index of xericity $(\mathrm{S}=\mathrm{PE} / \mathrm{M})$ is 1.8 . Pluviometric quotient $(\mathrm{Q}=2000 \mathrm{P} /[(\mathrm{M}+\mathrm{m}+546.4) *(\mathrm{M}-\mathrm{m})]$ is 40.7 , and the precipitation regime is sub-Mediterranean (spring, autumn, winter, summer). Northeast winds predominate, thus north facing slopes are partly windward, whereas the south facing slopes are leeward. The north facing slopes are snow covered for a longer time than the south facing slopes.

The vegetation mostly consists of Festuca-dominated grasslands and traditionally has been grazed by sheep, cows and goats since the $19^{\text {th }}$ century. However, grazing pressure has gradually decreased over the last two decades due to declining livestock production.

\section{Vegetation sampling}

The taxonomy of vascular plants follows Davis (1965, 1985), Davis et al. (1988), Tutin et al. (1964, 1980), Güner et al. (2000) and Güner et al. (2012), respectively. All plant samples were preserved in the Herbarium of the Faculty of the Arts-Sciences of Ondokuz Mayis University (OMUB). Non vascular plants were omitted.

For sampling procedure, we considered the study area according to the north and the south facing slopes. Both of them occupied altitudes ranging between 2000 and $2500 \mathrm{~m}$. Five floristically and environmentally homogeneous sample plots were established with $100 \mathrm{~m}$ altitudinal intervals on each slope. Plot size was selected as 20 and $50 \mathrm{~m}^{2}$ (van der Maarel 2005). In total, 60 plots were obtained during the spring and summer months of 2015 and 2016. Phytosociological records were carried out by using the cover/abundance values proposed by Braun-Blanquet (1964) in each plot. In each plot, the slope degrees (\%), altitude (meters above the sea level), aspect and GPS coordinates were also logged. Aspect in degrees was transformed using the formula of Beers et al. (1966).

Plant associations were named according to the International Code of Phytosociological Nomenclature (ICPN) (Weber et al. 2000). Syntaxonomic interpretations were made by using the available phytosociological literature (Quézel 1973, Akman et al. 1987, Vural 1996, Mucina 1997, Parolly 1998 and 2004, Onipchenko 2002, Mucina et al. 2016). Plant life forms were identified according to Mueller-Dombois and Ellenberg (2002). EUNIS habitat code and names were identified according to Davies et al. (2004) and EUNIS habitat type hierarchical view (EEA 2017).

\section{Soil sampling and analysis}

From each plot, soil samples were taken at a depth of 20 $\mathrm{cm}$ from the topsoil. Soil samples were then air dried and sieved through a $2 \mathrm{~mm}$ mesh prior to analysis. Soil organic matter (\%) was determined using the Walkley and Black method (Black et al. 1965). Soil texture was determined using the Bouyoucus hydrometer method, and the clay content was expressed as $\%$. The $\mathrm{pH}$ values were measured in deionized water (1:1) and the soil nitrogen (\%) was determined by the micro Kjeldahl method. The soil phosphorus (ppm) was determined spectrophotometrically following the extraction by ammonium acetate. Soil potassium $(\mathrm{cmol}(+) /$ $\mathrm{kg}$ ) was determined using a Petracourt PFP-7 flame photometer after nitric acid wet digestion. The $\mathrm{CaCO}_{3}(\%)$ concentrations were determined using a Scheibler calcimeter. For the determination of soil moisture, freshly weighed soil samples were air dried for $48 \mathrm{~h}$ to calculate wet to dry mass ratios. 
These values were used to calculate soil moisture (gravimetric method) (Kacar 2009).

\section{Data analysis}

Prior to data analysis, 10 vegetation plots were subjectively excluded due to high heterogeneity and their uncertain positions. The resulting dataset of 50 plots and 160 species was classified by the PC-ORD program (McCune and Grace 2002), using Ward's method and the Jaccard similarity index as a resemblance measure. "Crispness of the classification" was used for the optimal number of clusters (Botta-Dukát et al. 2005). Diagnostic taxa for each group were defined in the JUICE program (Tichý 2002) by calculating the fidelity of each species to each group (Chytrý et al. 2002) using the $\varphi$-coefficient as the fidelity measure. Species with a fidelity of above $50(\varphi>50)$ were considered as diagnostic.

To detect gradients in species composition and speciesenvironment relations, canonical correspondence analysis (CCA) was performed by using the ECOM 2.1.3.137 version software programme (Seaby and Henderson 2007). Canonical correspondence analysis includes two matrices, one of which has 50 plots, classified into syntaxa by phytosociological analysis, $\times 160$ species (average $\%$ cover values of species corresponding to the transformations of the Braun-Blanquet scale as proposed by van der Maarel (1979) were $r=1,+=2$, $1=3,2 \mathrm{~m}=4,2 \mathrm{a}=5,2 \mathrm{~b}=6,3=7,4=8,5=9$ ) and second matrix 50 plots $\times 7$ environmental parameters (soil moisture (SM), soil pH, soil clay content (Clay), total soil nitrogen ratio $(\mathrm{N})$, aspect, altitude and slope). The interpretation of the results was made by the first two axes because only these two axes were statistically significant. Statistically significant variables that derived from CCA were shown by a bold number.

Species diversity was calculated as the Shannon-Wiener index at log base 10 (Magurran 2004) performed by using Biodiversity version 2.0 (McAlleece et al. 1997) software programme, respectively. Moreover, the comparison of growth form and species diversity parameters for the described communities was visualized by a Box-Whisker diagram prepared in SPSS 21.0 version (IBM Corp. 2012).

The data of the Şebinkarahisar (Giresun) State Meteorological Station, the nearest meteorology station to the study area, were used to explain the climatic properties.

\section{Results}

Cluster analyses yielded that vegetation of Eğribel Pass was shown by four main clusters (Fig. 1). Crispness of classification value verified that the data set was classified in four clusters. The most prominent split within the four-clusters concerned the cluster $\mathrm{C}$, which is clearly separated from the other clusters due to syntaxonomic distinction on the basis of the summed up average cover values of diagnostic species.

We defined two grassland associations and subassociations dominated by Festuca, and a cushion Juniperus scrub on the different slopes. The south facing slopes had drier soil

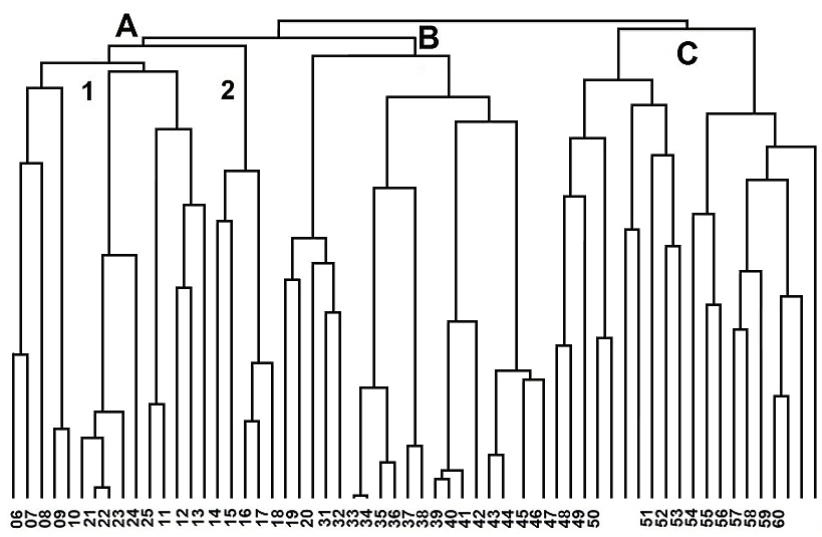

Fig. 1. Dendrogram of vegetation plots (50 plots and 160 species) of the Giresun Mountains. A: Bunio microcarpae-Festucetum pinifolii, 1: oxytropetosum lazicae, 2: verbascetosum froedinii, B: Lotus corniculati-Festucetum turcici, C: Alysso pseudo-mouradici-Juniperetum saxatilis stands.

conditions than the north facing slopes. Cluster A contained the plots sampled in the southern slopes in the study area. Festuca pinifolia var. pinifolia, Bunium microcarpum subsp. bourgaei, Veronica peduncularis and Lotus corniculatus var. alpinus were constant. We defined two subassociations from the cluster. Subassociations were formed by different environmental variables such as altitude, slope, soil organic matter and nitrogen ratios (Tab. 1). We propose the following name for the association and subassociations: Bunio microcarpae-Festucetum pinifoli ass. nova hoc loco (holotypus: plot 14 in On-line Suppl. Tab. 1), Bunio microcarpae-Festucetum pinifoli subass. oxytropetosum lazicae subass. nova hoc loco (holotypus:plot 10 in On-line Suppl. Tab. 1) and Bunio microcarpae-Festucetum pinifoli subass. verbascetosum froedinii subass. nova hoc loco (holotypus: plot 16 in On-line Suppl. Tab. 1), respectively. Oxytropis lazica and Verbascum froedinii were dominant taxa in the subassociations. Oxytropis lazica spread on mesic slopes while Verbascum froedinii occupied drier slopes.

Cluster B included plots where the vegetation was dominated by Festuca amethystina subsp. orientalis var. turcica, Lotus corniculatus var. corniculatus and Scorzonera cana var. radicosa in northern slopes. We named cluster B Lotus corniculati-Festucetum turcici ass. nova hoc loco (holotypus:plot 33 in On-line Suppl. Tab. 1). Bunio microcarpae-Festucetum pinifoli and Lotus corniculati-Festucetum turcici were differentiated by the bulk of Caricetea curvulae Br.-Bl. 1948 and Caricetalia curvulae Br.-Bl. in Br.-Bl. et Jenny 1926 species in these clusters puts them in these syntaxa. At the alliance level, their affiliation is clearly with Agrostio lazicae-Sibbaldion parviflorae Vural 1996 owing to the species diagnostic of alliance. Moreover, Molinio-Arrhenatheretea R. Tx. 1937 and Astragalo microcephali-Brometea tomentelli Quézel 1973 em. Parolly species participated in the floristic composition of both of them.

Cluster $\mathrm{C}$ which was coniferous cushion scrublands comprised of the plots sampled in the southern slopes in 
the study area and, dominated by Juniperus communis var. saxatalis, Alyssum pseudo-mouradicum and Dianthus zederbaueri. Cluster $\mathrm{C}$ is named as Alysso pseudo-mouradiciJuniperetum saxatilis ass. nova hoc loco (holotypus: plot 58 in On-line Suppl. Tab. 1). In the association, Astragalo microcephali-Brometea tomentelli Quézel 1973 em. Parolly,
Hyperico linarioidis-Thymetalia scorpilii Akman, Quézel, Yurdakulol, Ketenoğlu, Demirörs In all, 1987 species are present. The diagnostic species of Peduicularo comosaAsterion alpini Akman, Quézel, Yurdakulol, Ketenoğlu, Demirörs 1987 were represented in this association such as Aster alpina and Jasione supina subsp. pontica.

Tab. 1. The mean values environmental, soil parameters and species richness in the associations and their comparison with ANOVA test. The difference in letters indicates significant difference $(\mathrm{P}<0.05)$ between means according to Tukey's $(\mathrm{HSD})$ test among associations and subassociations. BG - between groups, WG - within groups; BFol - Bunio microcarpae-Festucetum pinifoli subass. oxytropetosum lazicae, BFvf - Bunio microcarpae-Festucetum pinifoli subass. verbascetosum froedinii, LF - Lotus corniculati-Festucetum turcici, AJ - Alysso pseudo-mouradici-Juniperetum saxatilis.

\begin{tabular}{|c|c|c|c|c|c|c|c|}
\hline Parameter & Associations & Mean \pm std. error & Sum of squares & $\mathrm{df}$ & Mean square & $\mathrm{F}$ & $\mathrm{P}$ \\
\hline \multirow[t]{4}{*}{ Aspect } & BFol & $0.68 \pm 0.21 \mathrm{~b}$ & & & & & \\
\hline & BFvfi & $0.32 \pm 0.09 \mathrm{~b}$ & $15.27(\mathrm{BG})$ & $3(\mathrm{BG})$ & $5.09(\mathrm{BG})$ & 17.13 & $<0.01$ \\
\hline & $\mathrm{LF}$ & $1.62 \pm 0.08 \mathrm{a}$ & $15.16(\mathrm{WG})$ & 51(WG) & $0.29(\mathrm{WG})$ & & \\
\hline & AJ & $1.44 \pm 0.14 \mathrm{a}$ & & & & & \\
\hline \multirow[t]{4}{*}{ Slope } & BFol & $24.33 \pm 2.22 \mathrm{~b}$ & & & & & \\
\hline & BFvfi & $42.00 \pm 0.81 \mathrm{a}$ & 2794.05(BG) & $3(\mathrm{BG})$ & 931.35(BG) & 17.92 & $<0.01$ \\
\hline & LF & $27.75 \pm 1.96 b$ & 2649.58(WG) & 51(WG) & 51.95(WG) & & \\
\hline & AJ & $39.50 \pm 0.89 \mathrm{a}$ & & & & & \\
\hline \multirow[t]{4}{*}{ Altitude } & BFol & $2290.86 \pm 16.69 \mathrm{a}$ & & & & & \\
\hline & BFvfi & $2113.10 \pm 14.16 \mathrm{~b}$ & 206244.59(BG) & $3(\mathrm{BG})$ & 68748.19(BG) & 6.19 & $<0.01$ \\
\hline & LF & $2257.70 \pm 35.55 \mathrm{a}$ & 566279.33(WG) & $51(\mathrm{WG})$ & 11103.51(WG) & & \\
\hline & $\mathrm{AJ}$ & $2245.50 \pm 10.13 \mathrm{a}$ & & & & & \\
\hline \multirow[t]{4}{*}{ Species richness } & BFol & $23.13 \pm 0.63 \mathrm{a}$ & & & & & \\
\hline & BFvfi & $26.90 \pm 1.90 \mathrm{a}$ & 929.97(BG) & $3(\mathrm{BG})$ & 309.99(BG) & 16.85 & $<0.01$ \\
\hline & $\mathrm{LF}$ & $17.50 \pm 1.09 \mathrm{~b}$ & 937.73(WG) & 51(WG) & 18.38(WG) & & \\
\hline & $\mathrm{AJ}$ & $27.30 \pm 0.86 \mathrm{a}$ & & & & & \\
\hline \multirow{4}{*}{ Soil moisture } & BFol & $6.23 \pm 0.96 \mathrm{ab}$ & & & & & \\
\hline & BFvfi & $3.59 \pm 1.06 \mathrm{~b}$ & 396.25(BG) & $3(\mathrm{BG})$ & $132.08(B G)$ & 10.71 & $<0.01$ \\
\hline & $\mathrm{LF}$ & $9.32 \pm 0.93 \mathrm{a}$ & 628.87(WG) & 51(WG) & 12.33(WG) & & \\
\hline & AJ & $2.54 \pm 0.09 \mathrm{~b}$ & & & & & \\
\hline \multirow[t]{4}{*}{$\mathrm{pH}$} & BFol & $4.65 \pm 0.12 \mathrm{~b}$ & & & & & \\
\hline & BFvfi & $5.10 \pm 0.19 \mathrm{~b}$ & $7.22(\mathrm{BG})$ & $3(\mathrm{BG})$ & $2.40(\mathrm{BG})$ & 11.21 & $<0.01$ \\
\hline & $\mathrm{LF}$ & $4.76 \pm 0.10 \mathrm{~b}$ & 10.95(WG) & 51(WG) & $0.21(\mathrm{WG})$ & & \\
\hline & AJ & $5.65 \pm 0.01 \mathrm{a}$ & & & & & \\
\hline \multirow[t]{4}{*}{ Silt } & BFol & $27.86 \pm 1.35 \mathrm{ab}$ & & & & & \\
\hline & BFvfi & $27.73 \pm 1.06 \mathrm{~b}$ & 527.07(BG) & $3(\mathrm{BG})$ & $175.69(\mathrm{BG})$ & 8.04 & $<0.01$ \\
\hline & $\mathrm{LF}$ & $32.69 \pm 1.24 \mathrm{a}$ & 1113.96(WG) & 51(WG) & 21.84(WG) & & \\
\hline & $\mathrm{AJ}$ & $24.39 \pm 2.17 \mathrm{~b}$ & & & & & \\
\hline \multirow[t]{4}{*}{ Sand } & BFol & $59.30 \pm 1.34 \mathrm{~b}$ & & & & & \\
\hline & BFvfi & $58.41 \pm 1.73 b$ & 738.76(BG) & $3(\mathrm{BG})$ & 246.25(BG) & 7.86 & $<0.01$ \\
\hline & $\mathrm{LF}$ & $55.42 \pm 1.54 \mathrm{~b}$ & 1596.41(WG) & 51(WG) & 31.30(WG) & & \\
\hline & $\mathrm{AJ}$ & $65.91 \pm 0.64 \mathrm{a}$ & & & & & \\
\hline \multirow[t]{4}{*}{$\mathrm{CaCO}_{3}$} & BFol & $2.79 \pm 0.24 \mathrm{a}$ & & & & & \\
\hline & BFvfi & $2.47 \pm 0.29 \mathrm{ab}$ & $5.97(\mathrm{BG})$ & $3(\mathrm{BG})$ & $1.99(\mathrm{BG})$ & 2.88 & 0.04 \\
\hline & LF & $2.57 \pm 0.19 \mathrm{ab}$ & 35.13(WG) & 51(WG) & $0.68(\mathrm{WG})$ & & \\
\hline & $\mathrm{AJ}$ & $1.82 \pm 0.06 \mathrm{~b}$ & & & & & \\
\hline \multirow[t]{4}{*}{ Organic matter } & BFol & $11.18 \pm 1.32 \mathrm{~b}$ & & & & & \\
\hline & BFvfi & $4.78 \pm 0.53 \mathrm{c}$ & $1123.63(\mathrm{BG})$ & $3(B G)$ & 374.54(BG) & 28.98 & $<0.01$ \\
\hline & $\mathrm{LF}$ & $15.65 \pm 0.82 \mathrm{a}$ & 659.14(WG) & 51(WG) & 12.92(WG) & & \\
\hline & $\mathrm{AJ}$ & $5.45 \pm 0.19 \mathrm{c}$ & & & & & \\
\hline \multirow[t]{4}{*}{ Total soil nitrogen } & BFol & $0.54 \pm 0.06 \mathrm{~b}$ & & & & & \\
\hline & BFvfi & $0.27 \pm 0.04 \mathrm{c}$ & $2.27(\mathrm{BG})$ & $3(\mathrm{BG})$ & $0.75(\mathrm{BG})$ & 24.66 & $<0.01$ \\
\hline & $\mathrm{LF}$ & $0.75 \pm 0.03 \mathrm{a}$ & $1.56(\mathrm{WG})$ & $51(\mathrm{WG})$ & $0.03(\mathrm{WG})$ & & \\
\hline & $\mathrm{AJ}$ & $0.27 \pm 0.09 \mathrm{c}$ & & & & & \\
\hline
\end{tabular}


HÜSEYINOVA R., YALÇIN E.

The syntaxonomic scheme for syntaxons in the study area is as follows:

Class: Astragalo microcephali-Brometea tomentelli Quézel 1973 em. Parolly

Order: Hyperico linarioidis-Thymetalia scorpilii Akman, Quézel, Yurdakulol, Ketenoğlu, Demirörs 1987

Alliance: Peduicularo comosa-Asterion alpini Akman, Quézel, Yurdakulol, Ketenoğlu,

Demirörs 1987

Association: Alysso pseudo-mouradici-Juniperetum saxatilis ass. nova hoc loco

Class: Caricetea curvulae Br.-Bl. 1948

Order: Caricetalia curvulae Br.-Bl. in Br.-Bl. et Jenny 1926

Alliance: Agrostio lazicae-Sibbaldion parviflorae Vural 1996

Association 1: Bunio microcarpae-Festucetum pinifoli ass. nova hoc loco

Subassociation 1.1: oxytropetosum lazicae subass. nova hoc loco

Subassociation 1.2: verbascetosum froedinii subass. nova hoc loco

Association 2: Lotus corniculati-Festucetum turcici ass. nova hoc loco

Hemicryptophytes were the dominant life form in all syntaxa, while chamaephytes and geophytes also contributed to the life form composition (Fig. 2). Alysso pseudo-mouradici-Juniperetum saxatilis had the highest species richness and most diverse syntaxon while Lotus corniculati-Festucetum turcici was the syntaxon with lowest species richness and the least diverse syntaxon (Figs. 3 a,b). The environmental factors and species richness of syntaxa were statistically different (Tab. 1). Lotus corniculati-Festucetum turcici contained species related to plots with more humid, nitrogenous, silty soil, rich in organic matter, while Alysso pseudo-mouradiciJuniperetum saxatilis had species related to plots with sandy soil and plots of greater inclination.

The first two CCA axes were significant $(\mathrm{P}<0.001)$ according to the Monte-Carlo permutation test. Eigenvalue of axis 1 was 0.70 and explained $13.75 \%$ of total variance, while eigenvalue of axis 2 was 0.51 and explained $23.87 \%$ of total

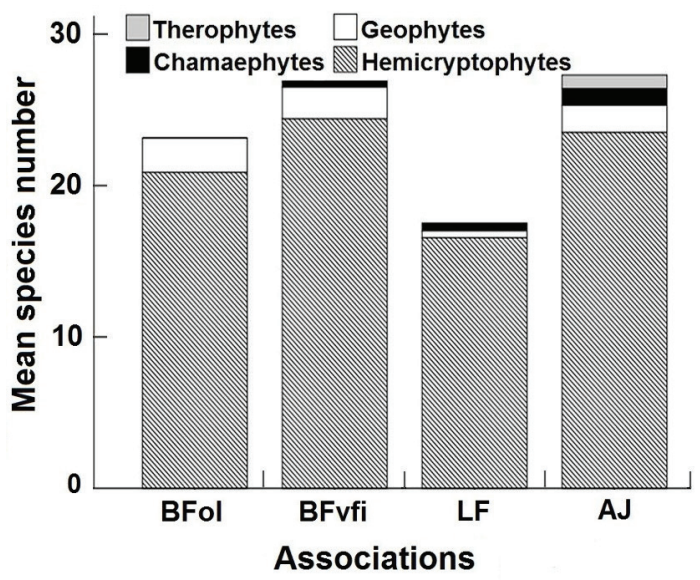

Fig. 2. Life form spectra for associations and subassociations. BFol - Bunio microcarpae-Festucetum pinifoli subass. oxytropetosum lazicae, BFvi - Bunio microcarpae-Festucetum pinifoli subass. verbascetosum froedinii, LF - Lotus corniculati-Festucetum turcici, AJ-Alysso pseudo-mouradici-Juniperetum saxatilis.
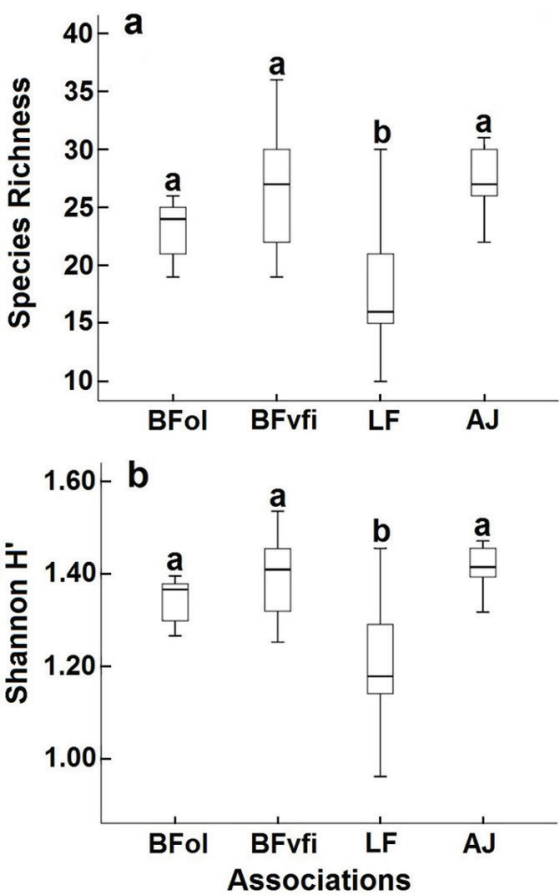

Fig. 3. Species richness (a) and Shannon diversity index values (b) for associations and subassociations. The difference in letters indicates the significant difference $(\mathrm{P}<0.05)$ between means according to Tukey's (HSD) test among associations and subassociations. Abbreviations for associations and subassociations are as in Fig. 2.

variance (On-line Suppl. Tab. 2). According to CCA ordination axes, aspect, slope, altitude, soil moisture, clay and nitrogen contents were important environmental parameters for the development of different vegetation types in the study (On-line Suppl. Tab. 2). The slope, proportion of soil moisture, clay and nitrogen were negatively correlated with the first and second CCA axes, while aspect and altitude were positively correlated with the second axis (Fig. 4). In the CCA ordination, Alysso pseudo-mouradici-Juniperetum saxatilis preferred higher soil moisture, clay and nitrogen 


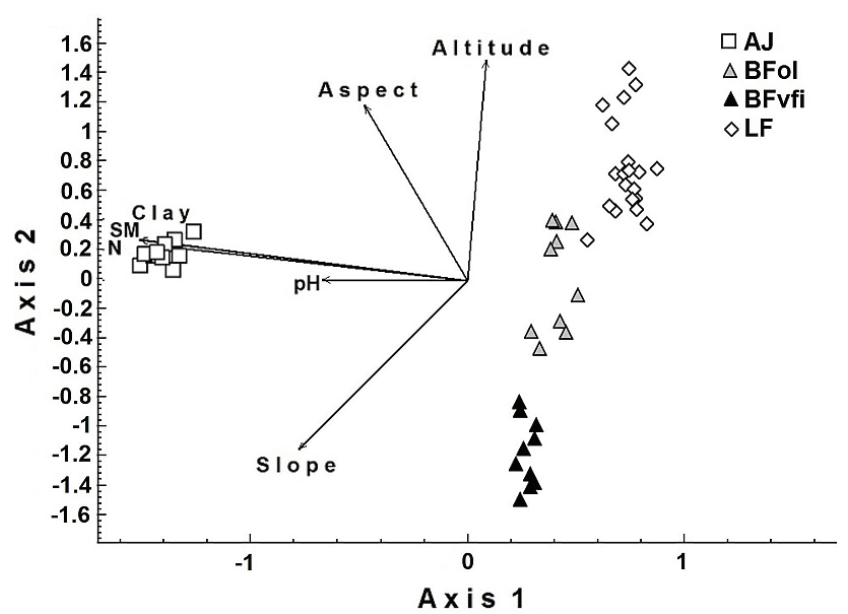

Fig. 4. Canonical correspondence analysis ordination diagram of the dendrogram groups related to environmental factors in the study area. Abbreviations for associations and subassociations are as in Fig. 2. SM - soil moisture ratio, $\mathrm{N}$ - total soil nitrogen ratio.

content in spite of the spread of Lotus corniculati-Festucetum turcici on the highest altitude slopes. Caricetea curvulae Br.Bl. 1948 plots were located in a separate position towards the right margin of the ordination space and showed high correlations with topographical factors such as altitude, slope and aspect (Fig. 4). Bunio microcarpae-Festucetum pinifoli and Alysso pseudo-mouradici-Juniperetum saxatilis spread on the south facing slopes in spite of Lotus corniculati-Festucetum turcici occupying the north facing slopes. The plots of Bunio microcarpae-Festucetum pinifoli subass. oxytropetosum lazicae spread on the landscapes that had higher altitudes and lower slopes than Bunio microcarpae-Festucetum pinifoli subass. verbascetosum froedinii plots.

\section{Discussion}

In the Eastern Black Sea region, detailed research dealing with vegetation of the highest mountains above the timberline began in the 1980s. In the first studies, Turkish authors (Düzenli 1988, Kılınç and Karakaya 1992, Vural 1996) recorded a number of vegetation plots from different alpine and subalpine communities. Düzenli (1988) investigated the vegetation in the alpine zone of Mount Tiryal (Artvin). He represented the alpine vegetation as associations Alchemillo-Campanuletea tridentate Quézel et Düzenli 1979 and Alchemillo-Campanuletalia tridentatae Quézel et Düzenli 1979, respectively. Vural (1996) studied the high mountain vegetation of Rize. In his paper, subalpine vegetation was considered within one class and two orders. Kılınç and Karakaya (1992), suggested that subalpine vegetation in the OrduÇambaşı Plateau should be included in the class Molinio-Arrhenatheretea R. Tx. 1937, order Arrhenatheretalia and class Alchemillo retinervis-Sibbaldietea parviflorae Vural 1996.

Aspect, slope and altitude influence the plant communities and environmental conditions in the Giresun Mountains. Consequently, in this study, different plant associa- tions and subassociations were defined. Vural (1996), in his study, formerly described Alchemillo retinervis-Sibbaldietea parviflorae Vural 1996, Alchemillo retinervis-Sibbaldietalia parviflorae Vural 1996 and Swertio ibericae-Nardetalia strictae Vural 1996. But Parolly (2004) proposed that all of them should be included in Caricetea curvulae Br.-Bl. 1948 and Caricetalia curvulae Br.-Bl. in Br.-Bl. et Jenny 1926. Onipchenko (2002) supported a similar syntaxonomic scheme for the subalpine vegetation of the Teberda Reserve, the Northwestern Caucasus. We agreed with this viewpoint and firstly classified the subalpine Festuca grasslands within these syntaxa in Turkey. At the alliance level, Agrostio lazicae-Sibbaldion parviflorae Vural 1996 was accepted by Parolly (2004) for subalpine grassland vegetation from northern Turkey. We also considered that alliance for the syntaxa dominated by Festuca in this study. A coniferous cushion scrub community spread at 2200-2300 meters altitude was dominated by Juniperus communis var. saxatilis in this study. Akman et al. (2014) previously reported a similar community on Ilgaz Mountain. In the present study, it was found that the bulk of Astragalo microcephali-Brometea tomentelli and $\mathrm{Hy}$ perico linarioidis-Thymetalia scorpilii species in the floristic composition of the coniferous cushion scrub association was dominated by Juniperus communis var. saxatilis. At the alliance level, the association affiliated with Peduicularo comosa-Asterion alpini Akman, Quézel, Yurdakulol, Ketenoğlu, Demirörs 1987. Cluster groups in dendrogram of plots that also reflected a floristic assemblage characterized by a mixture of species of Caricetea curvulae and Astragalo microcephali-Brometea tomentelli.

Hemicryptophytes were dominant in accordance with general characterisation of subalpine vegetation in this study. Hemicryptophytes were fairly common life form in alpine and subalpine landscape, which showed adaptations to snowbed environmental conditions by the strong persistence via plurennial stocks or dense turfs, above-ground renewal buds over winter, lateral spreading over short distances and generalistic diaspore dissemination (Komac et al. 2015, Scheepens et al. 2015). Nevertheless, considerable percentages of particular plant types (like therophytes, various kinds of chamaephytes, succulents, evergreens and berryproducers) generated a highly diversified alpine belt (Illa et al. 2006). Chamaephytes also presented low percentages in the floristic composition that were related to various stress conditions in this study. These plants mainly grew in infertile soils and were able to persist for many years with small above-ground lignified perennial structures (Sanz-Elorza et al. 2003, Schweingruber 2007).

In this study, the environmental factors influenced vegetation differentiation at different physiognomic and syntaxonomic levels (Onipchenko and Semenova 1995, Onipchenko 2002). Etzold et al. (2016) reported that altitude, slope and aspect were also the main topographical factors and formed different syntaxa in subalpine and alpine grassland vegetation in the northeastern Greater Caucasus of Azerbaijan. Noroozi et al. (2010) also reported that slope and aspect were also the main driving topographical factors on vegetation differentia- 
tion in the high alpine vegetation of the Tuchal Mountains (Central Alborz, Iran). Likewise, new plant associations and subassociations were described depending on altitude and aspect gradients, in our study. The position of Caricetea curvulae Br.-Bl. 1948 probably reflected a moisture gradient in terms of the longer persistence of snow. Altitude decreases temperature while increases precipitation that indirectly influence vegetation (Walther et al. 2005). Aspect could indirectly alter soil moisture and mineralization due to their effect on the solar radiation (Winkler et al. 2016). Therefore, we found that different plant associations grew on different slopes and humid soils. Gottfried et al. (1998) and Pauli et al. (1999) showed increasing elevation limits of alpine grassland from south-western to south-eastern slopes on Schrankogel in the central Eastern Alps. Besides, this study showed that south-exposed mountain slopes favour local-scale species richness, compared to the northern sides of the same mountains. This is consistent with the species-energy hypothesis (Wright 1983) and other temperature-related diversity hypotheses (Currie et al. 2004), suggesting temperature-driven processes as decisive determinants of vascular plant species richness (Winkler et al. 2016).

CCA reflected soil clay content being one of the important environmental factors for the floristic composition of subalpine vegetation. The soil particle size is determined by microtopography and fine-textured soils (mainly clay and silt) have higher water-holding capacity (Michalet et al. 2002). Zanelli et al. (2007) hypothesised that vegetation change has led to changes in soil chemistry and soil mineralogy. Clay minerals are often a weathering product of the near-surface that is dependent on the precursor minerals and the surrounding environmental conditions (Egli et al. 2008). In addition to this, the clay contents in soils are favourable for the immobilization of nutrient ions and enzymes. Subalpine soils have high contents of total nitrogen, which also explains the lower activities and microbial biomass in these soils. Nitrogen is generally a limiting factor for soil biological processes (Margesin et al. 2009). We also found that soil clay and nitrogen content had an impact on vegetation differentiation in subalpine belts in the Black Sea Mountains.

New subalpine syntaxa were identified in the Black Sea Mountains in Turkey. They were included in two classes Caricetea curvulae Br.-Bl. 1948 and Astragalo microcephaliBrometea tomentelli Quézel 1973 em. Parolly. Astragalo microcephali-Brometea tomentelli Quézel 1973 em. Parolly was widespread on the different altitudes and bedrocks in eastern and inner Anatolia. This study revealed that this class penetrated into the Black Sea high mountain chains. It also showed that Caricetea curvulae Br.-Bl. 1948 and Astragalo microcephali-Brometea tomentelli Quézel 1973 em. Parolly were distributed together on different altitudes and aspects in the subalpine belt in Black Sea Mountains in Turkey. However, these classes diverged in some environmental parameters such as altitude, slope, aspect, soil nitrogen, moisture and clay contents.

The EUNIS habitat classification is important for species, habitat types and designated sites compiled in the framework of Natura 2000 (Davies et al. 2004, Özüdoğru and Duygu 2009). Festuca-dominated grasslands could be included in Pontic alpine grasslands as EUNIS habitat code E4.441. The Juniperus communis dominated syntaxa were classified in EUNIS by the habitat code and name F3.16 and Juniperus communis scrub in Europe, respectively. We newly described a Juniperus scrub syntaxon which could not be included in this habitat code and name. Therefore, we have proposed a new EUNIS habitat code and name for this syntaxon as F3.165 and Black Sea subalpine juniper thickets, respectively.

\section{Acknowledgement}

This study was funded by the Research Council of Giresun University (Project number: FBA 250414-79). Special thanks are due to Ridvan Kızılkaya (PhD), Ali Kavgacı (PhD), and to Sıddık Yüksel (English specialist) for their valuable contributions.

\section{References}

Akman, Y., Quezel, P., Yurdakulol, E., Ketenoglu, O., Demirors, M., 1987: La végétation des hauts sommets de Ilgaz Dağ. Ecologia Mediterranea 13, 119-129.

Akman, Y., Ketenoğlu, O., Kurt, L., Vural, M., 2014: The steppe vegetation of Inner Anatolia. Palme Publications, Ankara.

Beers, T. W., Dress, P. E., Wensel, L. C., 1966: Notes and observations: aspect transformation in site productivity research. Journal of Forestry 64, 691-692.

Black, C. A., Evans, D. D., Ensminger, L. E., White, J. L., Clark, F. E., Dinauer, R. C., 1965: Methods of Soil Analysis. American Society of Agronomy, Wisconsin.

Botta-Dukát, Z., Chytrý, M., Hájková, P., Havlová, M., 2005: Vegetation of lowland wet meadows along a climatic continentality gradient in Central Europe. Preslia 77, 89-111.

Boztuğ, D., Jonckheereb, R., Wagnerb, G. A., Yeğingil, Z., 2004: Slow Senonian and fast Palaeocene-Early Eocene uplift of thegranitoids in the Central Eastern Pontides, Turkey: apatite fission-track results. Tectonophysics 382, 213-228.
Braun-Blanquet, J., 1964: Pflanzensoziologie. Grundzüge der Vegetationskunde. Springer-Verlag, Wien and New York.

Cannone, N., Sgorbati, S., Guglielmin, M., 2007: Unexpected impacts of climate change on alpine vegetation. Frontiers in Ecology and the Environment 5, 360-364.

Chytrý, M., Tichý, L., Holt, J., Botta-Dukát, Z., 2002: Determination of diagnostic species with statistical fidelity measures. Journal of Vegetation Science 13, 79-90.

Currie, D. J., Mittelbach, G. G., Cornell, H. V., Field, R., Guégan, J. F., Hawkins, B. A., Kaufman, D. M., Kerr, J. T., Oberdorff, T., O’Brien, E., Turner, J. R. G., 2004: Predictions and tests of climate-based hypotheses of broad-scale variation in taxonomic richness. Ecology Letters 7, 1121-1134.

Davies, C. E., Moss, D., Hill, M. O., 2004: EUNIS habitat classification revised 2004. Report to: European Environment AgencyEuropean Topic Centre on Nature Protection and Biodiversity.

Davis, P. H., 1965-1985: Flora of Turkey and the East Aegean Islands Vols. 1-9. Edinburgh University Press, Edinburgh. 
Davis, P. H., Mill, R. R., Tan, K. 1988: Flora of Turkey and the East Aegean Islands Suppl. 1. Edinburgh University Press, Edinburgh.

Düzenli, A., 1988: Nouveaux syntaxons phytosociologiques pour la végétation de Turquie. Ecologia Mediterranea 14, 143-148.

Egli, M., Mirabella, A., Sartori, G., 2008: The role of climate and vegetation in weathering and clay mineral formation in late Quaternary soils of the Swiss and Italian Alps. Geomorphology 102, 307-324.

Etzold, J., Münzner, F., Manthey, M., 2016: Sub-alpine and alpine grassland communities in the northeastern Greater Caucasus of Azerbaijan. Applied Vegetation Science 19, 316-335.

EEA (European Environment Agency), 2017: Retrieved February 15, 2017 from http://eunis.eea.europa.eu/habitats-codebrowser.jsp

Gottfried, M., Pauli, H., Grabherr, G., 1998: Prediction of vegetation patterns at the limits of plant life: a new view of the alpine-nival ecotone. Arctic and Alpine Research 30, 207-221.

Güner, A., Özhatay, N., Ekim, T., Kaya, H. C. B., 2000: Flora of Turkey and the East Aegean Islands (Suppl. 2), Vol. 11. Edinburgh University Press, Edinburgh.

Güner, A., Aslan, S., Ekim, T., Vural, M., Babaç, M. T., 2012: List of Turkish Plants (Vascular Plants). Nezahat Gökyiğit Botanik Bahçesi ve Flora Araştırmaları Derneği Yayını, İstanbul (in Turkish).

Hamzaoğlu, E., 2006: Phytosociological studies on the steppe communities of East Anatolia. Ekoloji 15, 29-55.

Hein, P., Kürschner, H., Parolly, G., 1998: Phytosociological studies on high mountain plant communities of the Taurus mountains (Turkey) 2. Rock communities. Phytocoenologia 28, 465-563.

Holtmeier, F. K., Broll, G., 2005: Sensitivity and response of northern hemisphere altitudinal and polar treelines to environmental change at landscape and local scales. Global Ecology and Biogeography 14, 395-410.

IBM Corp., 2012: Released: IBM SPSS Statistics for Windows, Version 21, Armonk, NY: IBM Corp.

Illa, E., Carrillo, E., Ninot, J. M., 2006: Patterns of plant traits in Pyrenean alpine vegetation. Flora-Morphology, Distribution, Functional Ecology of Plants 201, 528-546.

Kacar, B., 2009: Soil Analysis, Nobel Publications, Ankara.

Kılınç, M., Karakaya, H., 1992: A phytosociological investigation on the subalpine and alpine vegetation of Çambaşı Plateau (Ordu). Turkish Journal of Botany 16, 195-206.

Komac, B., Pladevall, C., Peñuelas, J., Conesa, J. V., Domènech, M., 2015: Variations in functional diversity in snowbed plant communities determining snowbed continuity. Plant Ecology $216,1257-1274$.

Magurran, A. E., 2004: Measuring biological diversity, Blackwell Publication, UK.

Margesin, R., Jud, M., Tscherko, D., Schinner, F., 2009: Microbial communities and activities in alpine and subalpine soils. FEMS Microbiology Ecology 67, 208-218.

McAleece, N., Gage, J. D. G., Lambshead, P. J. D., Paterson, G. L. J., 1997: BioDiversity Professional statistics analysis software. UK.

McCune, B., Grace, J. B., 2002: Analysis of Ecological Communities. MjM Software Design, Glenden Beach, OR, USA.

Michalet, R., Gandoy, C., Joud, D., Pages, J. P., Choler, P., 2002: Plant community composition and biomass on calcareous and siliceous substrates in the northern French Alps: comparative effects of soil chemistry and water status. Arctic, Antarctic, and Alpine Research 34, 102-113.

Mucina, L., 1997: Conspectus of classes of European vegetation. Folia Geobotanica 32, 117-172.
Mucina, L., Bültmann, H., Dierßen, K., Theurillat, J. P., Raus, T., Čarni, A., Sumberova, K., Willner, W., Dengler, J., Garcia, R. G., Chytrý, M., Hajek, M., Di Pietro, R., Iakushenko, D., Pallas, J., Daniëls, F. J. A., Bergmeier, E., Guerra, A. S., Ermakov, N., Valachovic, M., Schaminée, J. H. J., Lysenko, T., Didukh, Y. P., Pignatti, S., Rodwell, J. S., Capelo, J., Weber, H. E., Solomeshch, A., Dimopoulos, P., Aguiar, C., Hennekens, S. M., Tichý, L., 2016: Vegetation of Europe: Hierarchical floristic classification system of vascular plant, bryophyte, lichen, and algal communities. Applied Vegetation Science 19, 3-264.

Mueller-Dombois., D., Ellenberg, H., 2002: Aims and methods of vegetation ecology. The Blackburn Press, New Jersey.

Noroozi, J., Akhani, H., Willner, W., 2010: Phytosociological and ecological study of the high alpine vegetation of Tuchal Mountains (Central Alborz, Iran). Phytocoenologia 40, 293-321.

Onipchenko, V.G., 2002: Alpine Vegetation of the Teberda Reserve, the Northwestern Caucasus. Veröff Geobot Inst ETH Zürich 130.

Onipchenko, V. G., Semenova, G. V., 1995: Comparative analysis of the floristic richness of alpine communities in the Caucasus and the Central Alps. Journal of Vegetation Science 6, 299-304.

Özüdoğru, E., Duygu, A. E., 2009: Assessment of Natura 2000 Protected Areas Ecological Network within the Context of Turkey's Accession Stage. Ankara Üniversitesi Çevre Bilimleri Dergisi 1, 16-24 (in Turkish).

Parolly, G., 1998: Phytosociological studies on high mountain plant communities of the South Anatolian Taurus mountains 1. Scree plant communities (Heldreichietea): a synopsis. Phytocoenologia 28, 233-284.

Parolly, G., 2004: The high mountain vegetation of Turkey-A state of the art report, including a first annotated conspectus of the major syntaxa. Turkish Journal of Botany 28, 39-63.

Pauli, H., Gottfried, M.,Grabherr, G., 1999: Vascular plant distribution patterns at the low-temperature limits of plant life - the alpine-nival ecotone of Mount Schrankogel (Tyrol, Austria). Phytocoenologia 29, 297-325.

Pfeiffer, T. Ž., Maronić, D. Š., Zahirović, V., Stević, F., Zjalić, M., Kajan, K., Ozimec, S., Mihaljević, M., 2016: Early spring flora of the Sub-Pannonic steppic grassland (NATURA 2000 site) in Bilje, northeast Croatia. Acta Botanica Croatica 75, 157163.

Quézel, P, Pamukcuoglu, A., 1970: Vegetation des hautes des montagnes d'Anatolie Nord-Occidentale. Israel Journal of Botany 19, 348-400.

Quézel, P., 1973: Contribution à l'étude phytosociologique du masif du Taurus. Phytocoenologia 1, 131-222.

Rehder, H., Gökçeoğlu, M., Gebauer, G., Güleryüz, G., 1994: Die Vegetation des Uludağ-Gebirges (Anatolien). Phytocoenologia 24, 167-192.

Sanz-Elorza, M., Dana, E. D., González, A., Sobrino, E., 2003: Changes in the high-mountain vegetation of the Central Iberian Peninsula as a probable sign of global warming. Annals of Botany 92, 273-280.

Seaby, R. M. H., Henderson, P. A., 2007: Environmental Community Analysis version 2.1.3.137. Pisces Conservation LTD. IRC House, The Square, Pennington, Lymington Hampshire, SO41 8GN, UK.

Scheepens, J. F., Frei, E. S., Stöcklin, J., 2015: Relationship between phenotypic differentiation and glacial history in a widespread Alpine grassland herb. Alpine Botany 125, 11-20.

Schweingruber, F. H., 2007: Wood structure and environment. Springer Science and Business Media. Berlin.

Tichý, L., 2002: JUICE, software for vegetation classification. Journal of Vegetation Science 13, 451-453. 
Tappeiner, U., Tasser, E., Tappeiner, G., 1998: Modelling vegetation patterns using natural and anthropogenic influence factors: preliminary experience with a GIS based model applied to an Alpine area. Ecological Modelling 113, 225-237.

Tatl1, A., 1987: A phytosociological investigation on the Allahuekber Mountains. Turkish Journal of Botany 11, 169-193.

Tutin, T. G., V. H., Heywood, N. A., Burges, D. M. Moore, D. H., Valentine, S. M., Webb, W. D. A., 1964-1980: Flora Europaea Vol. 1-5. Cambridge University Press, Cambridge.

Uysal, I., Karabacak, E., Oner, Kurt, F., 2011: A syntaxonomical study of the pseudo-alpine vegetation of Kazdagi (Turkey) and two new endemic associations. Ekoloji 20, 88-96.

Van Der Maarel, E., 1979: Transformation of cover-abundance values in phytosociology and its effects on community similarity. Vegetatio 39, 97-114.

Van Der Maarel, E., 2005: Vegetation ecology- an overview, In: Van Der Maarel, E. (ed.),Vegetation ecology, 1-52, Blackwell Publishing Company. USA.

Vogiatzakis, I. N., 2012: Introduction to the Mediterranean mountain environments, In: Vogiatzakis, I. N. (ed.), Mediterranean mountain environments, 1-8, Wiley-Blackwell Publishing Company, UK.

Vonlanthen, C. M., Bühler, A., Veit, H., Kammer, P. M., Eugster, W., 2006: Alpine plant communities: a statistical assessment of their relation to microclimatological, pedological, geomorphological, and other factors. Physical Geography 27, 137154.

Vural, M., 1996: The high mountaine vegetation of Rize. Turkish Journal of Botany 20, 83-102.
Walther, G. R., Beißner, S., Burga, C. A., 2005: Trends in the upward shift of alpine plants. Journal of Vegetation Science 16, 541-548.

Weber, H. E., Moravec, J., Theurillat, J. P., 2000: International code of phytosociological nomenclature. $3^{\text {rd }}$ edition. Journal of Vegetation Science 11, 739-768.

Winkler, M., Lamprecht, A., Steinbauer, K., Hülber, K., Theurillat, J. P., Breiner, F., Choler, P. Ertl, S., Girón, A. G., Rossi, G., Vittoz, P., Akhalkatsi, M., Bay, C., Alonso, J. L. B., Bergström, T., Carranza, M. L., Corcket, E., Dick, J., Erschbamer, B., Calzado, R. F., Fosaa, A. M., Gavilán, R. G., Ghosn, D., Gigauri, K., Huber, D., Kanka, R., Kazakis, G., Klipp, M., Kollar, J., Kudernatsch, T., Larsson, P., Mallaun, M., Michelsen, O., Moiseev, P., Moiseev, D., Molau, U., Mesa, J. M., di Cella, U. M., Nagy, L., Petey, M., Pușcaș, M., Rixen, C., Stanisci, A., Suen, M., Syverhuset, A. O., Tomaselli, M., Unterluggauer, P. Ursu, T., Villar, L., Gottfried, M., Pauli, H., 2016: The rich sides of mountain summits-a pan-European view on aspect preferences of alpine plants. Journal of Biogeography 43, 2261-2273.

Wright, D. H., 1983: Species-energy theory - an extension of species-area theory. Oikos, 41, 496-506.

Yavuz, F., Fuchs, Y., Karakaya, N., Karakaya, M. Ç., 2008: Chemical composition of tourmaline from the Asarcik $\mathrm{Pb}-\mathrm{Zn}$ $\mathrm{Cu} \pm \mathrm{U}$ deposit, Şebinkarahisar, Turkey. Mineralogy and Petrology 94, 195-208.

Zanelli, R., Egli, M., Mirabella, A., Giaccai, D., Abdelmoula, M., 2007: Vegetation effects on pedogenetic forms of $\mathrm{Fe}, \mathrm{Al}$ and $\mathrm{Si}$ and on clay minerals in soils in southern Switzerland and northern Italy. Geoderma 41, 119-129. 